УДК 339.54

DOI: https://doi.org/10.37320/2415-3583/16.3

Шароян Ф.А.

аспірант

Київський національний університет імені Тараса Шевченка

\title{
КЛЮЧОВІ ЕТАПИ РОЗРОБЛЕННЯ СТРАТЕГІЇ ДИВЕРСИФІКАЦЇ̈ НА МІЖНАРОДНИХ РИНКАХ
}

\begin{abstract}
Досліджено проблематику формування стратегії диверсифікації підприємств на міжнародних ринках з урахуванням сучасних тенденцій та принципів. Виявлено головні причини та иілі розроблення стратегії диверсифікачії у діяльності на міжнародних ринках. Визначено поняття стрижневих компетенџій для підприємств під час аналізу сильних та слабких сторін із метою визначення напряму диверсифікаиії. Складено основні етапи розроблення стратегії диверсифікаиії на міжнародних ринках із більш детальним описом кожного з етапів. Розроблено поетапну модель стратегічного аналізу диверсифікації з метою визначення ефективності корпоративноі стратегї підприємства та оцінки відповідності сучасним умовам ринку. Визначено низку принципів формування стратегї диверсифікації для інноваційно орієнтованих промислових підприємств з їх подальшим описом. Розглянуто питання ефективних кордонів у проиесі визначення напряму диверсифікації та оцінки ефективності запропонованого напряму диверсифікації. Використано теорію транзакційних витрат для аналізу ефективних кордонів компанії. Розкрито питання інтеграчійних процесів як одного з методів диверсифікаційного росту підприємств. Уведено поняття оптимального розміру підприємства або структури підприємства в проиесі оцінки ефективності запровадження розробленої стратегії диверсифікачії на міжнародних ринках.
\end{abstract}

Ключові слова: стратегія диверсифікаиії, міжнародні ринки, стратегічний аналіз диверсифікаиії, інтеграизйні процеси, розміри компаній.

Постановка проблеми. Інноваційна орієнтація промислового підприємства вимагає нових теоретичних підходів до процесів диверсифікації господарської діяльності. Генезис методологічних підходів у даній сфері показує, що портфельний підхід поступився місцем ресурсному підходу, тобто принципово змінився пріоритет пошуку джерела конкурентної переваги. Якщо раніше фахові спеціалісти шукали причини і джерела диверсифікації у зовнішньому конкурентному середовищі, то в сучасних умовах джерелом конкурентної переваги стають ключові компетенції, якими володіє підприємство. Диверсифікація бізнесу, що розглядається як самостійна стратегічна альтернатива, сприяє забезпеченню ринкової маневреності промислової компанії, й у цьому сенсі теорія і практика стратегічного менеджменту розглядають іiі як одну з ключових корпоративних стратегій.

Аналіз останніх досліджень і публікацій. Проблематикою розроблення стратегії диверсифікації займалися такі вітчизняні та іноземні науковці: А. Павленко, А. Старостіна, В. Герасимчук, Є. Панченко, М. Мартиненко, І. Березін, Н. Добрянська, С. Шевельов, Г. Мінцберг, І. Ансофф, Г. Чезборо, Д. Тиса, Д. Деніелс, Г. Грінлі, Р. Грант, А. Томпсон, Дж. Стрікленд, Р. Коуз. Більшість із указаних науковців виділяе етапи розроблення стратегії диверсифікації в певних умовах чи окремого напряму диверсифікації або в межах національної економіки чи в рамках диверсифікації всередині підприємства. Єдиної думки щодо визначення ключових етапів розроблення стратегії диверсифікації на міжнародних ринках немає.

Мета статті полягає в узагальненні ключових етапів розроблення стратегії диверсифікації та визначення найвагоміших принципів стратегічного аналізу для забезпечення більшої ефективності впровадження диверсифікації міжнародної діяльності на стадії розроблення стратегії диверсифікації.

Виклад основного матеріалу. Питання диверсифікації на міжнародних ринках виникає у підпри- ємств усе частіше. Головними причинами розроблення стратегії диверсифікації можуть бути зниження рівня конкурентоспроможності на ринках, збільшення рівня ризиків від діяльності на існуючих ринках і існуючих продуктів, недоотримання потенційного прибутку в умовах обмеження ресурсів і виробництва та багато іншого. Саме формування стратегій диверсифікації спирається на стрижневі компетенції, які виникають на промисловому підприємстві. Прикладом стрижневих компетенцій можуть бути продуктові інновації, які можна реалізувати як продуктову лінійку, здатну задовольнити попит у декількох галузях чи секторах національної (світової) економіки. Сам набір стрижневих компетенцій є непостійним і тим більше отриманим ззовні, а постійно змінюється системою. Тому стратегії, засновані на інноваціях, не можна віднести до навмисних стратегій. Останні відповідають стратегіям у термінології Г. Мінцберга, вони зініціюються знизу вгору і не можуть бути сформовані виходячи 3 директивних установок топ-менеджменту, хоча очевидно, що вище керівництво підприємства контролює цей процес, прогнозує ефективність і можливість розроблення конкретної інновації до того чи іншого терміну i, відповідно, стимулює ту структурну ланку, де дана інновація розробляється [1].

Важливим є розгляд самого процесу розроблення корпоративної стратегії диверсифікації. Основні етапи розроблення стратегії представлено на рис. 1 .

Ключовим етапом розроблення стратегії диверсифікації $\epsilon$ аналіз та визначення сильних та слабких сторін бізнесу, оскільки на даному етапі можливо визначити, за рахунок чого можна здійснювати диверсифікацію діяльності підприємства, та визначити цілі диверсифікації. Після аналізу та визначення цілей слід розглянути існуючі напрями диверсифікації з метою досягнення поставлених цілей. Напрямів диверсифікації може бути безліч: експортна диверсифікація, продуктова диверсифікація, диверсифікація 
Етапи розроблення стратегії диверсифікації

\section{1) Аналіз сильних та слабких сторін бізнесу}

2) Пошук напрямів диверсифікації

3) Оцінка напрямів для диверсифрікації

4) Аналіз загального портфеля інвестицій

Рисунок 1 - Етапи розроблення стратегій диверсифікації

Джерело: складено автором

фінансових надходжень, диверсифікація ресурсів та ін. Оцінивши найбільш відповідні напрями диверсифікації до поставлених цілей, уже можливо перейти до аналізу та загальної оцінки портфеля інвестицій за вибраним напрямом диверсифікації. Наведені етапи розроблення стратегії диверсифікації $є$ загальними для більшості підприємств. Але варто відзначити, що етапи формування стратегії диверсифікації для окремо взятого підприємства слід адаптувати під особливості діяльності підприємства та ринкових чинників.

Для того щоб оцінити, наскільки ефективна корпоративна стратегія диверсифікації діяльності підприємства, а також визначити іiі відповідність сучасним умовам ринку, необхідно провести стратегічний аналіз диверсифікації діяльності організації (рис. 2).

Стратегія диверсифікації діяльності є потужним інструментом, за допомогою якого значно збільшується дохід організації та ії̈ конкурентоспроможність у цілому. Однак даний процес може обернутися значним збитками, тому необхідно проводити стратегічний аналіз диверсифікації діяльності підприємств, який дає відповіді на важливі питання.

Слід зазначити, що в ході реалізації стратегії диверсифікації на підприємстві можуть виникнути деякі проблеми і ризики, такі як [2]:
1) інертність стратегії до змін у часі;

2) відсутність підтримки з боку співробітників;

3) відсутність системи взаємодії із зовнішнім середовищем, неефективні внутрішня взаємодія й інформаційне середовище;

4) високі витрати на реалізацію стратегії;

5) недостовірність інформації, що використовується, та ін.

Щоб на практиці виникало менше таких проблем, необхідно дуже ретельно проводити стратегічний аналіз диверсифікації діяльності підприємств, її можливостей і загроз, а також оцінку основних параметрів. Саме це дасть змогу підприємству уникнути великої кількості недоліків і помилок під час вибору тієї чи іншої стратегії.

Промислові підприємства $є$ одними 3 найбільш капіталомістких суб'єктів господарювання, саме тому їм дуже важко швидко реагувати на ринкові зміни та адаптуватися до них. Саме тому розроблення стратегії диверсифікації на міжнародних ринках для промислових підприємств є актуальним питанням в умовах збільшення кількості протекціоністських заходів на міжнародних ринках. Найбільш пристосованими до диверсифікаційного росту є інноваційно орієнтовані промислові підприємства. На основі аналізу праць науковців можна запропонувати методичні принципи

\begin{tabular}{ll}
\hline $\begin{array}{c}\text { Етапи } \\
\text { стратегічного } \\
\text { аналізу }\end{array}$ & $\begin{array}{l}\text { 1) Вивчення та оцінка існуючого стану фірми та її дій } \\
\text { диратегічного характеру }\end{array}$ \\
\cline { 2 - 2 } диверсифікації & 2) Матричний аналіз диверсифікованого портфеля
\end{tabular}

3) Оцінка привабливості галузі

4) Порівняння господарських підрозділів

5) Порівняння перспективності господарських підрозділів на основі показника зростання прибутку

6) Аналіз стратегічної відповідності

7) Ранжування підрозділів за інвестиційною пріоритетністю

8) Розроблення корпоративної стратегії диверсифікації

Рисунок 2 - Стратегічний аналіз процесу диверсифікації діяльності організації 
формування стратегії диверсифікації інноваційно орієнтованих промислових підприємств [3]:

- Вибудовування вертикально інтегрованої системи з використанням нерівномірності розвитку регіонів.

Слід планувати кооперацію вже на стадії розроблення кінцевої продукції, коли визначається місце виготовлення окремих вузлів і формується замовлення на їх виробництво для провідних вітчизняних і зарубіжних фірм. До продажу продукції слід залучити незалежних дилерів. 10-12\% статутного капіталу повинно належати головній компанії. Відповідно до вимог моделі п'яти сил конкуренції М. Портера, ні на частку постачальників, ні на частку споживачів не повинно припадати більше 20\% від загального обсягу поставок сировини і комплектуючих, а також реалізації готової продукції, щоб виключити їх диктат у сфері ціноутворення та номенклатури виробів.

- Використання подвійних технологій (горизонтальна диверсифікація в родинні галузі), що дає змогу істотно скоротити витрати на НДДКР і технологічну підготовку виробництва.

Дана стратегія спрямована на виробництво конкурентоспроможної продукції у стратегічних галузях промисловості: цивільному авіабудуванні, атомній енергетиці, космічних технологіях, інформаційних і нанотехнологіях. Так, наприклад, понад 30 базових подвійних технологій упроваджено в агропромисловий комплекс, будівельну індустрію, медичну промисловість, легку і харчову промисловість, міське господарство: надпластичні деформування, дифузійне зварювання титанових і алюмінієвих сплавів, електрофізична обробка для зміцнення і підвищення ресурсу інструменту.

- Участь у створенні автономних венчурів [1].

Такими виступають автономно керовані спеціальні підрозділи. Окрім дрібних автономних ризикових фірм, велике поширення набувають внутрішні венчури, створювані великими корпораціями. Йдеться про автономну групу фахівців (або бригад), яка здійснює інноваційний проєкт усередині компанії. У таку групу, крім автора проєкту (як правило, це керівник групи), входять фахівці 3 дослідницького, виробничого та інших функціональних відділів. Їй надаються юридична і фінансова (у межах встановлених лімітів) самостійність, право підбору кадрів. Учасники проєкту отримують стимулюючі виплати в індивідуальному порядку за результатами як технічної, так і комерційної реалізації нововведення. У разі успіху внутрішні венчурні групи перетворюються на новий, теж самостійний виробничий підрозділ компанії. Саме так компанія IBM на початку 80 -х років створила своє виробниче відділення з випуску персональних ЕОМ, яке лише через рік стало їх найбільшим у світі виробником [4].

Більшість великих металургійних корпорацій США застосовує систему внутрішніх венчурних компаній. При цьому вони з чималою вигодою для себе використовують той факт, що здебільшого головним мотивом створення нововведення $€$ прагнення винахідників, людей із багатими творчими ідеями самостійно реалізовувати свій дослідницький задум.

Після переходу до ринкових відносин кордони компаній як господарських одиниць збігалися з формальними межами промислових підприємств, але це не забезпечувало ефективності. Процеси реструктури- зації, спрямовані на розукрупнення існуючих підприємств, різко підвищили транзакційні витрати і створили передумови подальшої інтеграції та перегляду кордонів організацій. Більшість радянських підприємств мала неефективну структуру організації і не мала стратегічної стійкості в умовах становлення ринкових відносин. Для забезпечення стійкості багатьом приватизованим підприємствам було необхідно знижувати транзакційні витрати, виділяти неефективні структурні підрозділи і вводити нові виробництва. У першій половині 1990-х років досить інтенсивно йшли процеси поділу підприємств, виділення структурних підрозділів у дочірні компанії, продаж активів, а в другій половині десятиліття набули поширення процеси другого типу: приєднання компаній, створення бізнес-груп [5].

Зростання компанії нерозривно пов'язане з питанням визначення iї ефективних кордонів. Проблему ефективності кордонів компанії вперше розглянув Р. Коуз [6, с. 233]. Рішення про виробництво (або купівлю) продукції залежить від величини відповідних транзакційних витрат: організація виробництва всередині компанії краще ринкового механізму, якщо витрати використання ринкового механізму (транзакційні витрати) вище порівняно $з$ витратами адміністрування всередині підприємства. Таким чином, фірма розширюватиме свою діяльність до тих пір, поки витрати на проведення транзакцій усередині компанії нижче витрат реалізації відповідних транзакцій за допомогою ринку. Якщо компанії або ієрархічні структури виявляють більшу ефективність у проведенні економічних транзакцій порівняно з ринком, то ці транзакції, згідно з Коузом, виявляються інтерналізованими всередині компанії. Подібна інтерналізація транзакцій дає можливість компаніям використовувати ефект масштабу (ефект зниження витрат на виробництво продукції з ростом обсягу виробництва) і ефект мережі (коли спільне виробництво, наприклад двох продуктів, обходиться дешевше їх роздільного виробництва). У цьому разі межі компанії можуть бути визначені 3 урахуванням меж дії ефекту від масштабу [8].

Використовуючи теорію транзакційних витрат для аналізу ефективних кордонів компанії, можна зробити висновок: якщо горизонтальні межі компанії визначаються переважно ефектом масштабу або мережевим ефектом, то вертикальні кордони залежать від балансу між мотивацією стимулювання інвестицій у специфічні активи і мотивацією підвищення ефективності.

Для аналізу ефективних кордонів промислових підприємств велике значення мають:

- кількість факторів виробництва, придбаних за певний період промисловим підприємством;

- кількість використаних виробничих факторів за певний період;

- кількість виробленої за певний період продукції;

- кількість витрачених за певний період грошових коштів;

- існування певної організації;

- використання певного місця і т. д.

Розвиток підприємства на базі однієї і/або декількох груп елементів призводить до того, що якісний і кількісний вибір оптимальних розмірів визначає можливість підвищення продуктивності та досягнення високих результатів. Разом із тим закономірно виникає проблема кількісного вибору розмірів і встановлення числа контр- 
ольованих проміжною системою елементів базової системи. Визначення управлінського потенціалу впливає не лише на розмір окремої одиниці, а й на організаційну структуру в цілому, оскільки від неї залежать кількість площин системи, експозиція горизонтального напряму i вертикальний розподіл сукупної системи.

У цілому, кажучи про проміжні системи та їхній вплив на організації, слід зазначити, що йдеться про ступінь керованості базовими системами. Проміжні системи можуть скоординувати більше базових систем, і цей фактор буде визначати оптимальний розмір організації. Витрати на розвиток проміжних систем не завжди виправдовуються тим зиском, який утворюється в процесі росту підприємства за рахунок більшої інтеграції базових систем. Іншими словами, йдеться про керованість цілою організацією, оптимальну взаємодію всіх рівнів управління починаючи з базового рівня і закінчуючи вторинними проміжними системами. Зі збільшенням кількості базисних систем збільшується ступінь їх інтеграції, відповідно, зростає ієрархія проміжних систем [1].

Традиційна точка зору являє конфігурацію організації як рівне число ієрархії або рівнів управління. Однак у дійсності розгляд організації не можна обмежити лише ієрархічними зв'язками, також існують і інші організаційні механізми координації та інтеграції, у тому числі горизонтальні і дифузні.

Інтеграція і координація дають можливість подолати розрив між ситуаціями сьогодення і майбутнього в плані розвитку зовнішніх зв'язків, що впливає на розмір підприємства. У структурі інтеграційних зв'язків підприємство передбачає оптимізацію розмірів свого зростання виходячи з інших критеріїв, аніж в умовах вільного ринку. Невизначеність майбутньої ситуації робить структуру більш складною і тим самим збільшує розміри підприємства, яке діє у цих умовах. Підприємство, яке не охоплене коопераційними зв'язками, не завжди має можливість швидко змінити розмір, незважаючи на сприятливу кон'юнктуру [6].

Інтеграційна взаємодія підприємства 3 іншими однопрофільними і різнопрофільними підприємствами впливає на оптимізацію його розміру в рамках даної взаємодії. При цьому інтеграція не виступає як винятково зовнішній фактор оптимізації, вона передбачає зміну внутрішньої структури підприємства, універсалізацію випуску або, навпаки, посилення тієї чи іншої спеціалізації. В умовах вертикального диверсифікованого зростання або комбінування оптимальний розмір підприємства визначається критерієм спеціалізації в рамках усієї інтегрованої системи. Відповідно, інтеграція змінює параметри зміни оптимального розміру, дає можливість збільшити його на підставі нової функціональної орієнтації. У цьому разі оптимальний розмір повинен забезпечувати співвідношення обсягу зовнішніх закупівель і доданої вартості. Дотримуючись класичного підходу, у визначенні оптимального розміру підприємства для кожної інтегрованої системи існує єдиний критерій оптимізації розмірів кожного елемента, кожного окремого підприємства. Усі підприємства повинні мати приблизно рівну рентабельність і рівне співвідношення зовнішніх закупівель і доданої вартості. Тут йдеться саме про системну стандартизацію і, відповідно, про критерії оптимізації розмірів основних виробничих ланок.
Відносно горизонтального диверсифікованого зростання об'єднання підприємств, що випускають однотипну продукцію, головним $є$ збільшення частки на ринку. Відповідно, оптимальним масштабом вважатиметься той, який забезпечує максимальний обсяг випуску. Якщо розглядати спосіб горизонтальної інтеграції злиття або поглинання, то оптимальним розміром підприємства партнера для злиття є різний розмір, а для поглинання краще менший розмір підприємства [1].

Оптимальний розмір підприємства, що входить у бізнес-структуру, слід оцінювати 3 позиції інвестиційного зростання виходячи з інвестиційного потенціалу. 3 одного боку, враховуються фінансові можливості бізнес-структури, а з іншого - очікувана віддача від конкретного підприємства в процесі його росту до оптимального розміру. Необхідно враховувати поєднання підприємств середніх і великих розмірів, що входять у бізнес-структуру. На кожному етапі становлення бізнес-структури пред'являтиметься різні вимоги до оптимального розміру підприємств, що вступають в неї, виходячи зі стратегії іiі подальшого розвитку та основних розмірів підприємств, що вже стали частиною бізнес-структури.

Як показує практика становлення вітчизняних i зарубіжних бізнес-структур, якщо на першому етапі відбувається об'єднання великих виробників і великих банків, то на наступному етапі утворилося ядро, що притягує середні і дрібні підприємства.

Оптимальний розмір підприємства, що входить в інтегровану структуру, залежить не лише від стадії становлення, а й від структури бізнес-групи. Мережева структура передбачає об'єднання близьких за розмірами підприємств, що пояснюється специфікою мережевої взаємодії. У векторній структурі розміри виробництв, що об'єднуються, визначаються організаційною сумісністю 3 головною компанією за принципом доповнюваності [7].

Розвиток інформатизації ускладнює визначення оптимальних розмірів підприємства, оскільки розмиває межу між продавцем і споживачем, а також між головними виробниками та постачальниками в системі інтеграції. Із розвитком відносин субконтрактації між дрібним і великим виробництвами оптимальний розмір можна розглядати як основний і додатковий. Основний розмір передбачає кордони головного виробництва, додатковий - кордони субконтрактних взаємодій із дрібним і середнім виробництвами. Збільшення основного виробництва призводить до збільшення оптимального додаткового обсягу, що відповідає внутрішньому i зовнішньому зростанню оптимального розміру підприємства. Велике і дрібне виробництва створюють один для одного критерії оптимізації. Розміри оптимізуються в контексті конкретної субконтрактної взаємодії [4].

Таким чином, модель оптимального розміру інтегрованої структури в процесі диверсифікованого зростання залежить від моделі об'єднання. Мережева i векторна моделі диверсифікованого зростання інтегрованого комплексу мають свої оптимальні розміри і діапазони зміни. Порівняно жорстко фіксований оптимальний розмір і більш вузький діапазон його зміни характерні для форми, де обмін інформацією, прямі і зворотні сигнали спрямовані від периферії системи до центру (радіальна форма взаємодії). У результаті диверсифікованого зростання такого роду організа- 
ції відбувається зростання бюрократичного апарату управління, зона вільного прийняття рішення i peaгування на зовнішні зміни звужується. У мережній моделі диверсифікованого зростання координаційні сигнали проходять між периферійними елементами, i зростання таких інтегрованих структур не строго обмежене рамками оптимізації [4].

Оптимальний розмір інтегрованої структури в процесі диверсифікованого зростання визначається взаємодією базових систем і первинних та вторинних проміжних систем. Збільшення базових систем призводить до збільшення проміжних систем виходячи з принципу керованості. Під час використання стратегії вертикального диверсифікованого зростання оптимальний розмір інтегрованої структури визначається критерієм спеціалізації в рамках усієї інтегрованої системи. Інтеграція визначає нові параметри зміни оптимального розміру, дає можливість збільшити його на підставі нової функціональної орієнтації. 3 одного боку, оптимізація розміру окремого підприємства в рамках інтеграції передбачає відповідність обсягу випуску на одній стадії виробництва обсягу переробки на іншій стадії, а з іншого - оптимізація розміру і структури підприємства диктує вирівнювання рівнів рентабельності виробництв, що входять в інтегровану структуру. Із позиції співвідношення величин зовнішніх закупівель і доданої вартості на кожному етапі переробки оптимізація розміру і структури підприємств пов'язана 3 досягненням рівної питомої ваги цих величин. Під час визначення оптимального розміру на кожній стадії росту підприємства необхідно враховувати темпи внутрішнього і зовнішнього зростання. У сучасних умовах ці два види росту взаємопов'язані: зміна форм виробництва і технології передбачає великі вкладення в інфраструктуру і зовнішню взаємодію [2].

Прикладом може бути диверсифіковане зростання металургійних підприємств після 2000-х років. На політику диверсифікованого зростання крупного бізнесу впливав фактор внутрішньої логіки розвитку. Значне зростання доходів і перехід до довгострокового бізнес-планування в умовах політичної стабілізації в країні дали змогу значно збільшити обсяги інвестицій, причому в кількох напрямах [5]:

- розвиток ресурсної бази;

- створення вертикально інтегрованої структури «сировина - напівфабрикати - кінцева продукція», що підвищує стійкість на ринках із недосконалою конкуренцією, до числа яких належить і російський;

- розширення ринків збуту;

- інвестування доходів від експорту в найбільш динамічні і прибуткові сектори економіки для диверсифікації бізнесу.

Усі ці напрями однозначно пов'язані 3 конкретними регіонами, де є нові родовища сировини, суміжні i переробні виробництва, концентрація динамічно зростає (нових видів зв'язку, харчової промисловості, агробізнесу та ін.). У результаті логіка розвитку і збільшення фінансових ресурсів призвели до різкого розширення територіальної експансії великого бізнесу.

Диверсифікація бізнесу була націлена на вибудовування його оптимальної структури. Загальний вектор розвитку змінився, почався процес об'єднання фрагментованого економічного простору країни. Під впли- вом фактора глобалізації багато компаній перейшли до більш раціональної побудови своїх промислових активів, покращуючи корпоративну структуру, зміцнюючи права власності, докуповуючи менш великі активи й оптимізуючи вертикальну і горизонтальну інтеграцію взаємопов'язаних виробництв. Усі ці процеси мають територіальну проєкцію, яка відображатиме зростання або зниження присутності бізнесу в регіонах [5].

Нині на території пострадянських республік диверсифіковане зростання крупного бізнесу триває за такими напрямами [9]:

- Внутрішньогалузева диверсифікація.

- Створення або покупка нових видів бізнесу.

Наприклад, УГМК створила групу «Трансмашхолдинг» (залізничне машинобудування).

- «Пов'язана» стратегія диверсифікації.

Багато великих компаній продовжують добудову вертикально інтегрованих зв'язків і експортної логістики в регіонах; якщо придбання були зроблені раніше, компанії посилюють контроль над власністю шляхом збільшення пакетів акцій.

- Придбання нових активів для добудови бізнесу.

- Експансія великих компаній в електроенергетику для зміцнення енергетичної безпеки.

- Поглинання менш великих, але привабливих промислових активів у нових або вже освоєних регіонах.

- Прискорена експансія середнього/великого бізнесу в регіоні.

Хоча компанії і бізнес-групи другого-третього рядів набагато поступаються найбільшим із фінансових ресурсів, вони є провідними в своїх підгалузях або у випуску окремих видів продукції, що дає змогу поглинати профільні підприємства в інших регіонах. Компанії з інших регіонів активніше розширюють територіальні зони впливу в реальному секторі економіки.

$\mathrm{У}$ цілому стратегія диверсифікованого зростання інтегрованих бізнес-груп стала «пов'язаною», зони впливу більшості великих компаній переважно залишалися стабільними або розширювалися за одночасного зміцнення позицій і диверсифікації власності в уже освоєних регіонах. Менші компанії галузевого великого i середньокрупного бізнесу активізували свою експансію в регіонах, має місце експансія вітчизняних бізнес-структур у третинний сектор економіки, тобто у великі міста. Ці тенденції диверсифікації бізнесу доповнюються транснаціонализацією (глобалізацією) найбільших вітчизняних компаній.

Висновки. Залежність країн, що розвиваються, від виробництва й експорту необробленої сировини робить їх уразливими від сировинних шоків, коливання цін і погіршення умов торгівлі, особливо з огляду на те, що еластичність попиту за доходом на сировинні товари є дуже низькою. У таких обставинах збагачення необробленої сировини перед його експортом розглядається як додавання нової вартості та веде до збільшення зайнятості і забезпечення більш стабільного та передбачуваного зростання на доходи від експорту для країн, що розвиваються. У цій ситуації диверсифікація експорту шляхом створення нових продуктів або поліпшення існуючих є основою для розвитку експортоорієнтованих країн. У процесі розроблення стратегії диверсифікації міжнародної діяльності підприємствам слід визначити для себе низку етапів розроблення та 
реалізації стратегї диверсифікації міжнародної діяльності. На етапі розроблення стратегії важливими є стратегічний аналіз диверсифікації, визначення шляхів та способів диверсифікованого росту. Це дасть змогу мінімізувати ризики невдалої реалізації розробленої стратегії. Для цього у статті наведено ключові принципи формування стратегії диверсифікації. Стратегія диверсифікації міжнародної діяльності залежатиме від іiї виду та стадії життєвого циклу компанії. Однак слід зазначити, що практика бізнесу настільки різноманітна, що одна модель диверсифікації не може бути визнана єдино правильною і достатньою. Можливе використання й інших стратегічних альтернатив, принципово нових підходів.

\title{
Список використаних джерел:
}

1. Стрікленд А.Дж., Томпсон-мол. А.А. Стратегічний менеджмент: концепції й ситуації для аналізу : учебник. Москва : Вильямс, 2012. 928 с.

2. Березін І.С. Маркетинг і дослідження ринків. Російська ділова література. 1999. 416 с.

3. Добрянська Н.А. Диверсифікація виробництва як фактор розвитку регіонального продовольчого ринку. Молодий вчений. 2013. № 8. C. 188-190.

4. Аронов А.М., Петров А.Н. Організація стратегічного планування на диверсифікованих підприємствах. Санкт-Петербург : СПбГУЕФ, 2001. 20 с.

5. Шевельов С.А. Диверсифікація виробництва в умовах транзитної економіки (організація і управління) : дис. ... канд. екон. наук. Алмати, 1999. 143 с.

6. Коуз Р.Г. Природа фірми / за ред. В.М. Гальперіна. Санкт-Петербург : Економічна школа, 1995. 189 с.

7. Katchova Ani L. The Farm Diversification Discount. The American Journal of Agricultural Economics. 2005. № 87(4). P. 984-994.

8. Кулик I.М. Сучасний стан та основні фактори розвитку чорної металургії в Україні. Бізнес Інформ. 2012. № 5. С. 116-121.

\section{References:}

1. Striklend A. J., Tompson Junior A.A. (2012) Strategichnii menegment: konceptsii i situatsii dlia analizu [Strategic management: concepts and situations for analysis]. Moscow. Viliams. (in Ukrainian)

2. Berezin I.S. (1999) Marketing $i$ doslidjenia rinkiv [Marketing and market research]. Russian business literature. (in Ukrainian)

3. Dobrianska N.A. (2013) Diversificatsia virobnitstva yak factor rozvitku regionalnoho prodovolchoho rinku [Diversification of production as a factor in the development of the regional food market]. Young scientist, no. 8, pp. 188-190.

4. Aronov A.M., Petrov A.N. (2001) Organizatsiia strategichnoho planuvania na diversificovanih pidpriemstvah [Organization of strategic planning in diversified enterprises]. St. Petersburg: Saint Petersburg State University of Economics. (in Russian)

5. Shevelov S.A. (1995) Diversificatsia virobnitstva v umovah tranzitnoi economiku (organizatsia I epravlinnya) [Diversification of production in a transit economy (organization and management)] (PhD Thesis), Almaty.

6. Coase R. H., Halperina V.M. (ed.) (1995) Priroda firmu [The Nature of Firm]. St. Petersburg: School of economics. (in Russian)

7. Katchova Ani L. (2005) The Farm Diversification Discount. The American Journal of Agricultural Economics, no. 87 (4), pp. $984-994$.

8. Kulik I.M. (2012) Suchasnii stan ta osnovni factori rozvitku chornoi metalurhii v Ukraini [Current state and main factors of ferrous metallurgy development in Ukraine]. Business inform, no. 5, pp. 116-121.

\author{
Sharoian Fato \\ Taras Shevchenko National University of Kyiv
}

\section{KEY STAGES OF DEVELOPING A DIVERSIFICATION STRATEGY IN INTERNATIONAL MARKETS}

The problems of formation of strategy of diversification of enterprises in the international markets taking into account modern tendencies and principles are investigated. The main reasons and goals of developing a diversification strategy in the international markets are identified. The concept of core competencies for enterprises in the analysis of strengths and weaknesses in order to determine the direction of diversification. The main stages of developing a diversification strategy in international markets with a more detailed description of each stage. A step-by-step model of strategic analysis of diversification has been developed in order to determine the effectiveness of the corporate strategy of the enterprise and assess compliance with modern market conditions. The key risks in the process of developing a diversification strategy in international markets are described, which may affect the qualitative assessment of the strategy and approaches to its implementation. A number of principles of formation of diversification strategy for innovation-oriented industrial enterprises with their further description are determined. Namely, such principles include: building a vertically integrated system using the uneven development of regions; the use of dual technologies (horizontal diversification into related industries), which can significantly reduce the cost of $R \& D$ and technological preparation of production; participation in the creation of autonomous ventures. The issue of effective borders in the process of determining the direction of diversification and evaluating the effectiveness of the proposed direction of diversification is considered. The theory of transaction costs is used to analyze the effective boundaries of the company. The key factors for the analysis of effective borders of industrial enterprises in the conditions of diversified growth are determined. The issue of integration processes as one of the methods of diversification of enterprises is revealed. The sizes of the companies in the process of diversification in the international markets are analyzed. The concept of the optimal size of the enterprise or the structure of the enterprise is introduced in the process of assessing the effectiveness of the implementation of the developed diversification strategy in international markets. The relationship between the model of the optimal size of the integrated structure in the process of diversified growth and the model of integration (network and vector models) is determined.

Key words: diversification strategy, international markets, strategic analysis of diversification, integration processes, size of business.

JEL classification: F13, L25, O24, P33 